\title{
The Challenge in Pain: The Delayed Bereavement at the Origin of the Act of Entry into Business of the Widow
}

\author{
Grace Moussaid $^{1}$, Trabulsi Hussein ${ }^{2}$, Hussein Akil ${ }^{2}$ \\ ${ }^{1}$ Faculty of Economics and Business Administration, University Bretagne Occidentale, France \\ ${ }^{2}$ Faculty of Economics and Business Administration, Lebanese university, Nabatieh, Lebanon \\ Correspondence: Hussein Akil, Faculty of Economics and Business Administration, Lebanese University, \\ Bretagne Occidentale, France University, Nabatieh, Lebanon.
}

\author{
Received: April 17, 2019 \\ Accepted: May 5, 2019 \\ Online Published: May 28, 2019 \\ doi:10.5539/ibr.v12n6p99 \\ URL: https://doi.org/10.5539/ibr.v12n6p99
}

\begin{abstract}
This paper is intended to explore the direct relationship between the widow's denied mourning and the influence of the loss of the husband manifested by a difficult or denied mourning. This research shows us that the widow has to assume the role of her departed husband immediately, and that it is quick, urgent and, most of the time, painful. The resulting dimensions of the difficult mourning that trigger in her the decision to resume and continue the work of the deceased.
\end{abstract}

We interviewed fifteen widows and highlighted the dimensions that surround the post-husband's loss. We thus discovered the keys of reading of this specific recovery.

Keywords: widow's mourning denied, specific recovery, immediate replacement of departed husband

\section{Introduction}

The recovery by the widow of the leader seems little or not treated, just as much as the human considerations which appear hidden to us, while it remains an answer to preserve the company and that to explore the human aspects which are its own could be the key to a successful recovery. This is why, for several reasons, we will pay particular attention to this work.

Firstly, we cannot ignore the death of the family business leader as a potential danger that causes a crisis due to a disruption of the organization; and, on the other hand, the grieving situation of the widow and the dimensions of her commitments in the family business (EF) (Labaki, 2013) to ensure the continuity of the deceased's work, often for a question of survival. The situation of widowhood in which she finds herself complicates her urgent and rapid entry into business. Early widowhood and bereavement are two aspects that we will explore in order to be able to find the mechanisms and the fundamental links of her intention to take over the family business. We will try to better understand the psychological springs of the "grieving widow" in mourning, to pierce her motivations for decision making recovery and how her intention to take over is manifested? But, at first, it seems fundamental to us to approach the early widowhood, then to trace the outlines of the mourning.

Early widowhood is an unnoticed contemporary phenomenon that is usually associated with older people, but it is far from being always the case. According to Delaunay-Berdaï (2006), in France, each year, around 24,000 women under 55 lose their spouse, compared to 6,000 men. In general, early widowhood affects 360,000 people, of whom almost $80 \%$ are women. These figures reflect an important phenomenon in which there is a strong gender component. A higher level of male mortality is well known to demographers and epidemiologists and, in the same vein, life expectancy of men in the socio-professional categories such as artisans, traders, business leaders is lower than that of women. This inequality is essentially linked to physical effort and occupational hazards such as accidents, suicides, etc. but also to diseases.

Early widowhood remains a poorly-known, even forgotten, phenomenon. When a spouse dies, it is clear that these "early widows" are often left alone with young children. This situation generates material and social difficulties. They thus assume a dual status, on the one hand that of "widow" and, on the other, that "of single-parent family". Studied from an anthropological point of view, the questions relating to death have made it possible to try to sketch the outlines of the behavior of men facing it. Thus, the death of a loved one does not correspond to a total disappearance from the existence of the surviving spouse. There is the disappearance of the 
body, ritualized by burial, allowing people to understand that they will never see their spouse again. However, sometimes the disappearance of the spouse does not mark the end of conjugal life. Indeed, the missing person remains present for the surviving spouse, through "marital memory" Caradec (2007). The latter reconstructs the past, transforms it, and thus establishes a new relationship with the deceased little by little. As Caradec (2007) points out, re-memorization uses various channels such as certain situations that recall an episode or a particular moment in conjugal life, material supports (domestic objects or places of memory). This work of memory is not only mental, it goes through the manipulation of the material supports of the company: the creations of the deceased like the business card, the e-mail address, the cup of coffee, the office, etc. However, the surviving spouse must decide on the future, objects, personal effects of his deceased spouse and, beyond that, objects to which his image remains attached. In our research, we imagine how difficult it is for the recovering widow to separate from the business created by her late husband. The challenge of widowhood is then to reorganize one's existence by finding a new meaning for it. In this sense, it means: to continue the entrepreneurial work while keeping alive its business.

\section{Ways of Understanding the Decision to Take Over the Grieving Theory}

The analytical framework of bereavement will describe the stages of mourning carried out or postponed by the widow, the demonstrations or not of these stages being directly related to her personal motivations to resume immediately after the death of her husband. We will approach the concept of grief from different angles and then present the analysis grid developed from the approach that seems relevant to us.

The theory of mourning, "theory of loss", should help us better understand the steps of the business recovery of the leader's widow. We therefore approach the major event that induces mourning: death.

Without going into a long "thanatological" discussion, our goal is to present death and its representations in our contemporary society. As part of our research, talking about death and coming to the emergence of representations of its consequences to be able to answer our problematic, was not easy to the extent that death was and remains a taboo subject. Indeed, the idea of death is unbearable for most people. The idea of eternity and the illusion of invulnerability are inscribed in us. In the near-future, we are promised "the death of death", "the revolution of life or how biotechnology will upset humanity" (Alexandre, 2011). We want to live and live with those we love. We cannot accept the idea of death or the final cessation of life, as the dictionary says. And yet, since the beginning of humanity, men are aware of their mortality.

This research focuses mainly on the entry into the company of the leader's widow following a crisis situation caused by the sudden disappearance (accident, suicide) of the key man (leader). The denial of death exists and talking about the death of another or of our own death is not an easy thing. Silence weighs on death, which explains why, in most family businesses, the question is avoided and it is very rare to hear a boss discuss his own death. However, we observe that at the legal, matrimonial and patrimonial level, steps are often taken to prepare for an unexpected death (sworn and written wills, life assurance policies, etc.)

The first publications on mourning date back to Abraham (1965), Freud (1968) and Lagache (1977). We retain from these works that the theory of mourning is a "theory of loss".

The loss of the head spouse is accompanied by associated losses that are also manifested in the loss of his social circle and the relationships he has developed within his professional network, internal and external. The widow must now face up to the change in her social status ; she is no longer the boss's wife, she is now the company's leader. As a result, she must go through a "relational transaction" (Arnould-Plaud, 2010) and rebuild her own network alone. The couple no longer existing, the couple's business relations are no longer the same, especially since these were largely, not to say exclusively, forged around the disappeared. Caradec (1998, quoted by Arnould-Plaud, 2010) notes a redefinition of identity imposed on the widow since "the couple is no more, the approach and the vision of those around them, the social positioning is changing".

The loss of "object of function" (Ribes, 2000, cited by Arnould-Plaud, 2010) now forces the widow to confront alone, on the one hand, the feeling of loneliness and misunderstanding, and on the other, the business world in connection with the company's internal and external stakeholders. The resumption of the conjugal craft business puts it in a dynamic of rapid adaptability, mixed with an extreme pain which is renewed and accentuated as many times as there are new situations to manage. The loss manifests itself in extreme physical and psychological expressions, which we discuss hereafter.

According to Bacquet and Hanus (2014), etymologically, the word mourning comes from the Latin "dolere" (to suffer), which is at the origin of the word dol which gave in French "deuil", but especially pain. Mourning is a "painful emotional state caused by the death of a loved one". It also refers to a period, "the period of pain and 
sorrow that follows this disappearance". Mourning is characterized by a personal experience, one speaks here of experience of mourning, and by a painful time. The word "mourning" has a social version in French terminology: "to mourn someone means to have lost and owed him a certain number of actions". Loss refers to "the fact of being separated by remoteness or by death, deprivation, the emptiness that results". "Mourning after death gives it a special character because of its radicality, its irreversibility, its universality and its implacability" (Hanus, 2000).

As we saw earlier, the loss of a loved one can cause a state of significant distress in the survivor. According to Bowlby (1980), "All available studies show that most women take a long time to overcome the death of their husbands and (...) almost always their health will suffer." According to doctors, the state that follows the death of a spouse is like a violent blow, a shock, causing insomnia, dizziness, nausea, etc. A long depression often follows. Thus, the body reacts physically to psychological suffering. There is also a state of fatigue, apathy and headaches. It should be noted that this physical upheaval, causes a deterioration in the state of health. As Bowlby (1980) points out, "if a minority of widows fail to recover their health status, the majority of those who reach it, or who approach it, will take two to three years to achieve it." These elements highlight the importance of difficulties for widows. In fact, the widowed wife will have to manage the takeover of the family business in extreme physical and psychological conditions.

The loss of the husband is a milestone event that, according to the authors cited above, is of a static and dynamic nature with a perspective considering post-loss. The notion of perspective places it in a process that is both active and reactive after the death of the leader. We are particularly interested in the notion of loss, because we think that it is at the center of the engagement of the widow's repreneurial act.

Death, the loss of the leader characterizes the first loss and implies the imbalance and conditions the associated losses. According to Stroebe (1996), it is "the loss of instrumental support, loss of validation support and loss of support for social support". The definitive disappearance of the person to whom we give and from whom we receive love represents a permanent state of lack. The well-established life on the functioning of a couple and the sharing of everything connected with it is no more. Feelings of security and assurance are shaken permanently, daily rituals are gone, and all forms of conjugal life belong to the past. The loss is even more painful if the spouse had the fundamental and major place in the life and survival of the couple. The impossibility of going back, avoidance, or repair, is no longer possible in time and the past is now synonymous with all representations of the husband. To deny oneself to this state of things is to keep alive the disappeared and to prevent him from definitively leaving the memory and in all that he may have left behind: the widow working to cultivate his presence through her works while fearing to forget it, she is afraid in the sense of Fauré, (2004), "not to be able to keep alive what cannot be shared anymore, (...), the loss is conjugated at all times". The feeling of instability, imbalance and disorganization results from the loss of the husband and his construct in the three time periods, the past, the present and the future. In this sense, the loss is seen as being "a crisis of life whose temporal thickness goes back to the individual past, to the definition of oneself in the present, and to the projection of oneself in the future" (Balk, 2004).

The process of mourning is also characterized by the manifestation of emotions and concerns. We can schematize it through the following stages: shock, confusion, research, acceptance, reintegration (Pereira, 1998).

According to Baudry (2003), the "Work of mourning" is done through conventions, customs, and rules that organize a framework within which the individual communicates to others his feelings. But society is not just an environment in which individuals would be actors and owners of their grief. It also gives form and, even more, existence to sorrow. According to Baudry (2003), grief is a constraint. It is a sociological approach to grief. To mourn corresponds to cultural imperatives, in which there are many many external and constraining frameworks in regional variants. Basically, mourning would not be a feeling, but a "directive". Whoever does not express his sentence would escape the collective rules.

According to the psychological and psychoanalytic approach, the mourning of the spouse requires a work of mourning studied, following Freud, by the psychologists who have identified the various manifestations and the different stages with the stupefaction, the denial and the revolt, the depression with its somatic, intellectual and emotional alterations (Bacqué and Hanus, 2014). According to the authors, three steps exist (Hanus, 1994), with shock, depressive state and recovery period, five-phase (Kübler-Ross, 1975), with refusal and isolation, irritation bargaining, depression and acceptance would break down the process of mourning.

As part of our research, we mobilize mourning events according to Bowlby (1978) with its four stages. We were convinced by the relevance of the analysis of this model. We analyze the grieving process of the widow who resumes according to this model. 
Mourning according to Bowlby (1978) is defined by four steps:

Emotional numbness that occurs just after the shock with the person who is in a state of distress, anger and denial of loss.

Languishing is the phase in which the person is terribly bored by the deceased and seeks him out. The person in mourning becomes preoccupied with the loss and the world seems empty and meaningless in the absence of the deceased. The bereaved person re-lives each memory, and is in search of the missing.

- Disorganization and despair, mentally re-living memories of the deceased, characterize the bereaved person who comes to accept the permanent loss and feels disoriented and agitated. Interpersonal relationships lose their warmth and spontaneity.

- It is in the reorganization phase that the mourning begins to fade and the person establishes new goals in his life by undertaking new activities. This process can take months or even years. The painful memories are less and less present and the grief is replaced by precious memories, pleasure and affection.

We can remember for our research, that this concept first enlightened us on how it is lived by the widow following the death of her leading husband; secondly, the duration and intensity of the mourning stages according to those chosen, namely, those of Bowlby (1978). These four steps are summarized in the following diagram. The process synthesized below is of course nonlinear and can see some skipped steps and have varying durations. It includes a phase of numbness in which distress and anger are manifested, a phase of languishing and searching for the loss suffered, a phase of disorganization and despair, and finally a phase of reorganization or phase of awareness and acceptance of the new situation with openness to the future.

\section{Methodology}

\section{Qualitative field approach}

This research is part of a comprehensive approach of the main actor of the takeover of the family business, the leader's widow, and of apprehension of the determining factors of her intentions when becoming the substitute. Based on qualitative research, we made sure to sample a number of special cases of widowed buyers. This allows us to discover what is general between them in order to be able to make possible comparisons. We therefore took into account the similarities and differences between our cases. We have selected any female survivor who has experienced a situation of widowhood and sudden entry into business, in the pain of the loss of the husband, with the diversity of their situation. This diversity was seen particularly in terms of legal status before the death of their spouse, age at the disappearance of their husband, participation or not in the creation of the case, family situation (mother or not), number of children and their age at the time of the father's death, sector of activity and geographical location. The principle of differentiality in the sense of Bertaux (2005: 29) was also observed in the selection of our cases. Indeed, although in the same situation and position of recovery, widows who took over were able to exercise their role with their own personality in the sense of "perception, apprehension, appreciation and action patterns. various manifestations closely related to those of their life course "(Bourdieu, 1986 cited by Bertaux, 2005, 29).

An ethno-sociological approach of multiple cases has been set up by favoring the method of life stories particularly adapted to the analyzed situation. We conducted interviews with 15 widows between 2013 and 2018 who took over the family business after the death of their husband, having perpetuated it and about to pass it on. The qualitative analysis made it possible to identify the key elements of the motivations of decision to pursue the family business. 


\section{Results}

The content analysis coding manual of interview revealed that several verbatim and themes that emerged

\begin{tabular}{|c|c|}
\hline Themes: Widows and & Verbatim examples \\
\hline $\begin{array}{c}\text { Numbness (between anger } \\
\text { and distress) }\end{array}$ & $\begin{array}{l}\text { The day when he arrived, he was already not well at all, I felt that there was a lot of tension in } \\
\text { the company, he was driving fast, I always told him to pay attention, he was not alone, at first } \\
\text { I was mad at him, the children asked me, I did not know what to say to them, I cried all the } \\
\text { time, I had no more words. (Widow 1) } \\
\text { It was brutal, we did not have time to prepare, in } 6 \text { months he was gone, } 6 \text { months something } \\
\text { like that, I always see myself in August when we saw the surgeon and that he told us clearly ; } \\
\text { it's over, there you do not see anything but black, it was not easy, it had an impact on the } \\
\text { future. (Widow 5) } \\
\text { I do not hide that there were difficult moments, I had insomnia, anxiety, and often you look at } \\
\text { yourself and you say the pit is attracting me, here is the black spot. (Widow 7) } \\
\text { These are all the things that fall on you, you did not ask anything, yes I admit, I had a hard } \\
\text { time with that and the rest. (Widow 10) }\end{array}$ \\
\hline $\begin{array}{l}\text { Languishing and searching } \\
\text { for the lost object }\end{array}$ & $\begin{array}{l}\text { I had to leave home, it was no longer possible, I had the impression that he was going to } \\
\text { return from his tour, and I was there waiting, while he was gone, definitely gone. (Widow } 4 \text { ) } \\
\text { It hurts, the pain annihilates you from the inside, you do not even know what you look like so } \\
\text { much as the days are alike and you are drowning in the problems, you are alone, you cry, but } \\
\text { you continue because it's like that, (...), I held on with drugs, I saw him everywhere, and I } \\
\text { told myself it's just a nightmare. (Widow 12) } \\
\text { He's still here, and then I put a picture of him smiling at the store, everyone said to me: it } \\
\text { looks like he's alive in the picture, and I said he was never dead and it's true for me, he wasn't } \\
\text { dead: he just left before me that's all. (Widow 14) } \\
\text { Sometimes I feel that he is more alive at the store just over there, when people come and talk } \\
\text { to me about him, it makes him live again, and makes me live, at home, it's empty, at the store } \\
\text { too his empty chair reminds me that he is no longer there; I will end up not sitting at this table } \\
\text { at noon. I'll work or I'll open sooner, what do you want me to say to you, I cannot accept it } \\
\text { like that; his departure, I cannot, so I speak, I talk to him, it's horrible when I realize that I am } \\
\text { alone, I collapse. (Widow 13) }\end{array}$ \\
\hline $\begin{array}{c}\text { Disorganization and } \\
\text { despair }\end{array}$ & $\begin{array}{l}\text { I did not know where to start, except I had to start somewhere and continue (...), but I was } \\
\text { there physically, but in my head, what happened to me was not true (Silence). (Widow 12) } \\
\text { But because I had to, it's true, it's for him, and for all that, I had to make a decision, quit my } \\
\text { job, it was a big risk for me, but I did it, and there I said to myself, but what should I begin } \\
\text { with? The garage, the customers, (...)? ". (Widow 7) } \\
\text { But the drama, unfortunately we had taken this bug business recently and it was important for } \\
\text { us and that's it, I find myself alone in front of this garage and I asked myself what should I } \\
\text { do? (Widow 11) } \\
\text { But afterwards, one is alone anyway, one is alone and if you have to make a decision you } \\
\text { have to do it alone, the others will not decide for you; people will not go into your personal } \\
\text { life and do it for you, but even sometimes it's too heavy, decide for everything especially } \\
\text { there, I'm never going to have anyone saying: well, what do you think about it? It's better like } \\
\text { that and wait for the answer, that would no longer exist. (Silence). (Widow 9) }\end{array}$ \\
\hline $\begin{array}{l}\text { Reorganization (the } \\
\text { rebound in the emergency) }\end{array}$ & $\begin{array}{l}\text { We have the most beautiful garage in the city, his dream, we have three employees so I make } \\
\text { the decision to continue and I say: well, either I continue and then it works, or I stop } \\
\text { everything but it was not at all what I wanted. (Widow 10) } \\
\text { Okay then, then I gathered the guys, I told them: I'm leaving my job and I'm not selling, for } \\
\text { him, for me and for you too, finding work around, it won't be easy for you, but think about it } \\
\text { and give me your answer quickly, we have no time. (Widow 12) } \\
\text { I did not shut down, Olivier opened that day, and every other day, he was like a son to my } \\
\text { husband and me, he cried like us, I could not have gone on without him and my daughters. So } \\
\text { he was buried on the } 15 \text { th and I opened the same week, we needed a week to prepare the } \\
\text { burial of my husband and the opening of the store. (Widow 8) } \\
\text { I had to decide whether I kept it or not, it was necessary to decide quickly, (...), we shared the } \\
\text { work, I worked on the administrative aspect and the customers who come to the store and the } \\
\text { employees worked on the building sites, it was okay, so we continued like this. (Widow } 3 \text { ) } \\
\text { At first, it was hard, now it's true with hindsight I realize it was hard and, you do not have } \\
\text { time to breathe, that's to say in six months what do I do? do we shut up in six months?, do we } \\
\text { suspend?, no we do not have time. (Widow 5) } \\
\text { I think we are so rushed, and everything else is a very special situation, (...). In fact J-F died } \\
\text { in June early in the season, we were engaged on many things; the summer, we don't question } \\
\text { ourselves, we re-open without thinking. (Widow 7) }\end{array}$ \\
\hline $\begin{array}{l}\text { Deferred or refused } \\
\text { bereavement }\end{array}$ & $\begin{array}{l}\text { His death was a disaster, by the way it was the first on all levels, I said I was there and I was } \\
\text { there because I felt that if I did not hold on, he would die again, and I did not want to, I did } \\
\text { not want to forget him, and I did not even want to be called a widow; I saw a psychiatrist who }\end{array}$ \\
\hline
\end{tabular}


told me you must mourn, mourning what? When? How to mourn my life? My husband's mourning? Of the love of my life? Is he crazy? So, I did not go there anymore and then I did not want to. (Widow 1)

I have to go by myself, but I must do it, I can do it for him, I'm not ready to leave everything, I'm not even sure now that I want to sell, no I cannot, it's no longer possible, what would I do? (Widow 6)

It is always difficult and then the mourning cannot be, it is not possible, to accept it is to make everything disappear with it, every day we live, it is for him, he must remain alive in us and in what he has built, every day, we do a little for that, always a little, that's it. (Widow 8)

There you go, that's all I had to say; otherwise concerning my mourning, it is not the moment and it will never be the moment, mourning means that it is finished, I manage my pain by working and as long as I am where my husband used to work, we have lived both in this place, so he's next to me here, he's next to me and I still live precious moments. (Widow 7)

The shelter was there not to think and not to feel pain, I could not bear the condolences; I was a widow?, I did not see myself in mourning, it was not the moment. (Widow 10)

We did as we could to deal with the pain, in the pain, all the rest and then the mourning, yes the mourning of my husband I have not yet completely mourned, the mourning of my husband, it has only been 2 years since I could talk about it . (Widow 12)

Afterwards, it is necessary to find the strength to keep moving forward in the fog and wait or rather make it disappear; you have to be really strong, after a lot of time and a lot of work, I was able to accept it and now I can finally mourn, his business is safe, he isn't dead. He's still here, he's not dead, he's alive. (Widow 9)

I think that at the beginning, it was to continue, after we do not think about it; grief, yes, but I will say that in everyday life, we make sure not to do it, we do not want to let it happen, we do not think about it, and we live in a village where we talk regularly of my husband; me too, we're grieving, it's hard and we live it differently with time and every day we do it without actually doing it, every day, we do it by talking about him, finding ourselves in the place where he was, but immediately after the death, we cannot mourn or even think about it, it's abstract, and then, if we think about doing it, we get the impression that everything is crumbling, everything disappears, so we cling to something that tells us that he has not left and he will live forever; I really do not know how to explain, it's real without being real, it's without interruption, here we must not feel that it changes, we do as if he were there. (Widow 3)

The analysis of the data brings out the major specificity of this entry into business, namely the sudden death and the emergency situation in which the widow finds herself. It brings out the influence of the loss of the husband as the first loss and the refusal of a second loss which is the family business created by him. The intention and the act of taking over the family affair left are essentially motivated by the refusal of mourning.

\section{Discussion}

Through extracts from the life stories of the 15 widows, we can only observe that the different phases of mourning manifest themselves for each of them. The state of extreme urgency makes the manifestation of the phases of mourning very fast and not very visible. It is therefore difficult to foresee the beginning and the end of the mourning in a sequential way. Indeed, the notion of urgency is so significant that some of these stages are deferred in time. It is important to get into business, take over the business and cope with it. We can therefore speak of complex bereavement and delayed bereavement, i.e., bereavement occurring in a time-lagged manner with respect to the date of death (Paturel and Paturel, 2009). We can also speak of refused mourning, because the refusal to mourn the husband is to keep in sight the company he created (his work). The decision of recovery is impelled notably by the refused bereavement. By refusing to mourn, widows cultivate the memory of the deceased through his work. It materializes and institutionalizes its presence by the continuation of the activity of its company or a part of it.

We are here, in this case, the continuity of the deceased's work to make it live through the company. The resisting widow refuses categorically to accept the "double loss". Indeed, the results clearly show that refusing to mourn the deceased implies refusing a second loss characterized by the company's closure. Since the widows who take over cannot act on the first loss, they expend all their energy to keep the entity alive and, in fact, prevent the second death of the husband through his work and thus the second loss.

Our research consisted in focusing on the widow's entry into business by highlighting, on the one hand, the post-traumatic factors following the death of the husband, which themselves condition the immediate and urgent recovery. The mourning of the wife allows the extension of the life of the leader by preventing his second death. The maintenance and perpetuation of the work that he has created on his own or with her, is reflected in the continuation of the life of the organization. 


\section{Perspective and Avenues of Research}

We cannot consider in our case a test of our conclusions, by the restraint of a quantitative device, or that of a device of longitudinal study, the character and the very essence of the subject there refuse. On the other hand, it seems entirely possible for us to proceed by comparison of cases, provided that we can have widowers who would agree to receive us and compare themselves to their experience of the recovery in terms of our model. Our goal is to be able to give voice to other widows by revealing the existence of this phenomenon.

\section{References}

Abraham, K. (1920). Perte objectale et introjection au cours du deuil normal et des états psychiques anormaux, Euvres complètes, Tome II, Paris, Éditions Payot, p. 258-265.

Alexandre, L. (2011). La mort de la mort, Éditions JC Lattès, p. 425.

Arnould-Plaud, C. (2010). La perte du conjoint chez la personne âgée: expérience de deuil, processus d'affliction et consommation de services de soutien social. Thèse de Doctorat en sciences de gestion, Ecole Supérieure de Commerce de Brest.

Bacqué, M. F., \& Hanus, M. (2014). Le deuil, Éditions PUF, 128 p.

Balk, D. E. (2004). Recovery following Bereavement : an examination of concept. Death Studies, 28, 361-374. https://doi.org/10.1080/07481180490432351

Baudry, P. (2003). Travail de deuil, travail du deuil, Études 2003/11 (Tome 399), p.475-482.

Bertaux, D. (2005). L'enquête et ses méthodes: Le récit de vie, Paris, $2^{\mathrm{e}}$ Éditions Armand Colin, pp.17-18.

Bourdieu, P. (1986). L'illusion biographique, Actes de la recherche en sciences sociales, $\mathrm{n}^{\circ}$ 62-63. https://doi.org/10.3406/arss.1986.2317

Bowlby, J. (1978). Attachement et perte : séparation, angoisse et colère. PUF.

Caradec, V. (2007). L'expérience du veuvage, Gérontologie et société, $\mathrm{n}^{\circ} 121$, p.179-193. https://doi.org/10.3917/gs.121.0179

Delaunay, B. I. (2006). Veuvage précoce et différence de genre, Recherches et prévisions, Mode de vie, pp.10.

Fauré, C. (2004). Vivre le deuil au jour le jour, Paris, Albin Michel.

Freud, S. (1917). Actuelles sur la mort et la guerre. Métapsychologie. Gallimard Folio Essais, 1968.

Kübler-Ross, E., \& Kessler, D. (2005). On Grief and Grievin: Finding the Meaning of Grief Thought the Five Stages of Loss, New York: Scribner.

Labaki, R. (2013). Beyond the awaking of a sleeping beauty: toward business models inclusive of the emotional dimension in entrepreneurship. Entrepreneurship Research Journal, 3(3), 265-276. https://doi.org/10.1515/erj-2013-0060

Lagache, D. (1977). Le travail de deuil, Paris, dans Euvres PUF, vol.1, 274- 248, 1938

Ribes, G. (2000). De l'inconsolable à la veuve joyeuse. Gérontologie et Société, 95, 87-98

Stroebe, W. (1996). The Role of Loneliness ans Social Support in Adjustement to Loss, Journal of Social an Personnal Relationships. https://doi.org/10.1037/e536912011-053

\section{Copyrights}

Copyright for this article is retained by the author(s), with first publication rights granted to the journal.

This is an open-access article distributed under the terms and conditions of the Creative Commons Attribution license (http://creativecommons.org/licenses/by/4.0/). 